\title{
The effects of low-pressure hyperbaric oxygen treatment before and after maximal exercise on lactate concentration, heart rate recovery, and antioxidant capacity
}

\author{
Si-Hwa Park, Sung-Jin Park, Mal-Soon Shin, Chang-Kook Kim* \\ School of Global Sport Studies, Korea University, Sejong, Korea
}

The purpose of this study was to investigate the effects of low-pressure hyperbaric oxygen (HBO) treatment before and after maximal exercise on lactate concentration and heart rate and antioxidant capacity. Ten healthy male college students were recruited from amateur soccer players. Subjects were performed a maximal exercise 3 times at intervals of at least 7 days according to the treatment method (control, pretreatment, posttreatment). Lactate concentration, heart rate, and antioxidant capacity were measured before, post, and after recovery 30 min of maximal exercise. The lactate concentration and heart rate of recovery 30 min was significantly lower in the low-pressure HBO treated group after the maximal exercise compared with the control group and the low-pressure HBO treated group before maximal exercise, and it could affect the removal of the fatigue substance caused by the maximal exercise. These results suggest that the low-pressure HBO treatment which is a new possibility for recovery of peripheral fatigue.

Keywords: Low-pressure hyperbaric oxygen, Lactate, Heart rate, Antioxidant capacity, Maximal exercise

\section{INTRODUCTION}

Fatigue refers to the inability to develop muscle strength and the power required for muscle contraction. Rapid removal of fatigue helps improve performance and exercise performance (Costill and Hargreaves, 1992). Lactate accumulation causes fatigue, refers to the inhibition of muscle contraction by the accumulation of various metabolites such as lactate, hydrogen ion, inorganic phosphoric acid, and ammonia. The production and accumulation of lactate in the body causes acidosis by decreasing the $\mathrm{pH}$, and it prevents oxidation of mitochondria and activation of enzyme (Robergs et al., 2004). In addition, lactate increases the protein binding of calcium ions in myoplasmic reticulum to negatively affect muscle contraction (Westerblad et al., 2002).

In humans, oxygen is used to produce energy and metabolism is inevitably incomplete during the metabolism (Gomes et al.,
2012). In many studies, exercise is known to increase reactive oxygen species. Reactive oxygen species refers to all types of deoxygenation that are unstable due to the absence of a pair of electrons such as hydrogen peroxide $\left(\mathrm{H}_{2} \mathrm{O}_{2}\right)$, hydroxyl radical $\left(\mathrm{OH}^{-}\right)$, superoxide ion (O2*) (Lambeth, 2004). Exercise causes active skeletal muscle contraction and increases reactive oxygen production (Powers and Jackson, 2008), leading to oxidative stress. Oxidative stress caused by the increase of active oxygen production causes damage to cells, resulting in various diseases such as diabetes, cardiovascular diseases and nervous system diseases, cancer caused by DNA damage, and promotion of aging (Reddy et al., 2009).

Hyperbaric oxygen (HBO) treatment is a minimal invasive treatment that inhales $100 \%$ oxygen in chambers pressurized at 2.0 to 2.5 atmospheres absolute (ATA) (Löndahl, 2012). Originally, HBO therapy has been useful in many injuries with edema and ischemia, such as wound healing and compression injuries. HBO
*Corresponding author: Chang-Kook Kim (ib https://orcid.org/0000-0002-3804-3917 School of Global Sport Studies, Korea University, 2511 Sejong-ro, Jochiwon-eup, Sejong 30019 , Korea

Tel: +82-44-860-1361, Fax: +82-44-860-1589, E-mail: kimck@korea.ac.kr

Received: September 21, 2018 / Accepted: October 27, 2018
This is an Open Access article distributed under the terms of the Creative Commons Attribution Non-Commercial License (http://creativecommons.org/licenses/by-nc/4.0/) which permits unrestricted non-commercial use, distribution, and reproduction in any medium, provided the original work is properly cited. 
therapy increases the level of dissolved oxygen in the blood and increases the oxygen partial pressure of the peripheral tissues and is known to alleviate symptoms caused by low-pressure such as carbon monoxide poisoning, decompression sickness, and arterial embolism (Shimoda et al., 2015; Tibbles and Edelsberg, 1996). Recently, HBO therapy with a lower pressure (1.2 to 1.3 ATA) method has been used not only for medical but also for personal use (Edwards, 2010).

In this study, we investigated the effects of low-pressure HBO therapy before and after maximal exercise on lactate concentration and heart rate recovery and antioxidant capacity.

\section{MATERIALS AND METHODS}

\section{Subjects}

Ten healthy male volunteers were recruited from amateur soccer players who had no medical problems such as musculoskeletal diseases, cardiovascular diseases, and who does not take medication.

Before the experiment, all subjects were explained about the purpose and procedure of the experiment, and the experimental agreement. A total of three exercise tests were performed at 7 days intervals. The subjects were randomly divided into three groups: control group $(n=10)$, low-pressure HBO-treated group before maximal exercise $(n=10)$, low-pressure HBO-treated group after maximal exercise $(n=10)$. The physical characteristics of subjects are shown in Table 1.

\section{Height and weight measurement}

Height was measured using an extensometer (Health mate 9600A, Sewoo, Seoul, Korea) and body weight was measured using Inbody 720 (Biospace, Seoul, Korea).

\section{Blood lactate concentration}

Blood lactate concentration was obtained from the capillary blood vessels at the tip of the right hand using finger-tip method. Blood samples were taken at rest, immediately after exercise, and at 30 min of recovery. Lactate was analyzed using an automatic blood lactate analyzer (Accutrend Plus, Roche, Germany).

Table 1. Characteristics of the participants $(n=10)$

\begin{tabular}{lr}
\hline Characteristic & Mean \pm SD \\
\hline Age $(\mathrm{yr})$ & $21.10 \pm 1.25$ \\
Height $(\mathrm{cm})$ & $173.70 \pm 3.49$ \\
Weight $(\mathrm{kg})$ & $69.14 \pm 8.01$
\end{tabular}

SD, standard deviation.

\section{Antioxidant capacity}

Antioxidant capacity was measured by finger-tip method using blood from the right capillary end capillary. The total antioxidant capacity of the body was determined by the BAP test (biological antioxidant potential) test. (BAP test, Diacron, Italy). Blood samples were taken at rest, immediately after exercise, and at $30 \mathrm{~min}$ of recovery.

\section{Maximal exercise load test}

Subjects were restricted from drinking and maintained a fasting state for $12 \mathrm{hr}$ before the experiment. All experiments were conducted under the same experimental conditions and at the laboratory temperature of $23^{\circ} \mathrm{C}-24^{\circ} \mathrm{C}$ and relative humidity of $55 \% \pm 3 \%$. Maximal exercise was performed using a treadmill (COSMED T150, Cosmos, Germany) according to a Bruce protocol. To ascertain whether or not a maximal effort was achieved during the test, the following criteria were considered; $>90 \%$ of the predicted maximum heart rate (220-age), a plateau in $\mathrm{VO}_{2}$, respiratory exchange ratio $>1.15$.

\section{Low-pressure HBO treatment}

Low-pressure HBO capsule was obtained from Saebo Energy (SB-153 ultimate, Seoul, Korea). Subjects were exposed to 30\% oxygen at 1.3 ATA for $30 \mathrm{~min}$. 1.3 ATA pressure is a pressure equivalent to $3-\mathrm{m}$ depth and is the pressure that can safely provide high-pressure oxygen.

\section{Statistical analysis}

All data were expressed as the mean and standard deviation. For comparisons among the time, time $\times$ group was used mixed analysis of variance and Bonferroni post hoc test was performed with $P<0.05$ as an indication of statistical significance.

\section{RESULTS}

\section{Lactate concentration}

The lactate concentration was presented in Table 2. The lactate concentration in the control group was $2.37 \pm 1.02 \mathrm{mmol}$ before exercise, $11.56 \pm 4.30 \mathrm{mmol}$ after exercise, and $7.06 \pm 2.24 \mathrm{mmol}$ after $30 \mathrm{~min}$ of recovery. Low-pressure HBO-treated group before maximal exercise was $1.93 \pm 0.68 \mathrm{mmol}$ before exercise, $11.99 \pm$ $3.57 \mathrm{mmol}$ after exercise, and $6.17 \pm 1.80 \mathrm{mmol}$ after 30 minutes of recovery. Low-pressure HBO-treated group after maximal exercise was $1.91 \pm 0.87 \mathrm{mmol}$ before exercise, $12.33 \pm 2.17 \mathrm{mmol}$ after exercise, and $4.23 \pm 1.67 \mathrm{mmol}$ after $30 \mathrm{~min}$ of recovery. Lac- 
Park SH, et al. • Low-pressure hyperbaric oxygen treatment

Table 2. Effect of antioxidant capacity on lactate concentration

\begin{tabular}{|c|c|c|c|c|c|c|c|c|}
\hline \multirow{2}{*}{ Variable } & \multirow{2}{*}{ Group } & \multirow{2}{*}{ Pretest } & \multirow{2}{*}{ Posttest } & \multirow{2}{*}{ Recovery $30 \mathrm{~min}$} & \multirow{2}{*}{ Postrecovery $\Delta \%$} & \multicolumn{3}{|c|}{ Mixed ANOVA } \\
\hline & & & & & & & $F$ & $P$-value \\
\hline \multirow[t]{3}{*}{ Lactate (mmol) } & PRT & $1.93 \pm 0.68$ & $11.99 \pm 3.57$ & $6.17 \pm 1.80^{a)}$ & -48.54 & & & \\
\hline & РOT & $1.91 \pm 0.87$ & $12.33 \pm 2.17$ & $4.23 \pm 1.67^{b)}$ & -65.69 & Time & 136.69 & 0.001 \\
\hline & CON & $2.37 \pm 1.02$ & $11.56 \pm 4.30$ & $7.06 \pm 2.20^{\mathrm{a})}$ & -38.92 & Time $\times$ group & 2.56 & 0.049 \\
\hline
\end{tabular}

Values are presented as mean \pm standard deviation.

PRT, pretreatment group; POT, posttreatment group; CON, control group; ANOVA, analysis of variance.

Different letters $(a-b)$ denote statistically significant differences $(P<0.05)$ after Bonferroni post hoc.

Table 3. Effect of low-pressure hyperbaric oxygen on heart rate

\begin{tabular}{|c|c|c|c|c|c|c|c|c|}
\hline \multirow{2}{*}{ Variable } & \multirow{2}{*}{ Group } & \multirow{2}{*}{ Pretest } & \multirow{2}{*}{ Posttest } & \multirow{2}{*}{ Recovery $30 \mathrm{~min}$} & \multirow{2}{*}{ Postrecovery $\Delta \%$} & \multicolumn{3}{|c|}{ Mixed ANOVA } \\
\hline & & & & & & & $F$ & $P$-value \\
\hline \multirow[t]{3}{*}{ Heart rate (bpm) } & PRT & $75.00 \pm 9.20$ & $185.80 \pm 7.33$ & $96.30 \pm 4.57^{a)}$ & -48.17 & & & \\
\hline & РОТ & $74.30 \pm 7.83$ & $184.70 \pm 8.00$ & $86.50 \pm 10.93^{b /}$ & -53.16 & Time & $3,045.80$ & 0.001 \\
\hline & CON & $75.50 \pm 7.41$ & $182.60 \pm 7.24$ & $97.80 \pm 7.48^{\mathrm{al}}$ & -46.44 & Timexgroup & 3.92 & 0.032 \\
\hline
\end{tabular}

Values are presented as mean \pm standard deviation.

PRT, pretreatment group; POT, posttreatment group; CON, control group; ANOVA, analysis of variance.

Different letters $(\mathrm{a}-\mathrm{b})$ denote statistically significant differences $(P<0.05)$ after Bonferroni post hoc.

Table 4. Effect of low-pressure hyperbaric oxygen on antioxidant capacity

\begin{tabular}{|c|c|c|c|c|c|c|c|c|}
\hline \multirow{2}{*}{ Variable } & \multirow{2}{*}{ Group } & \multirow{2}{*}{ Pretest } & \multirow{2}{*}{ Posttest } & \multirow{2}{*}{ Recovery 30 min } & \multirow{2}{*}{ Postrecovery $\Delta \%$} & \multicolumn{3}{|c|}{ Mixed ANOVA } \\
\hline & & & & & & & $F$ & $P$-value \\
\hline \multirow[t]{3}{*}{ Antioxidant capacity (mmol) } & PRT & $2,379.90 \pm 168.89$ & $2,692.50 \pm 198.59$ & $2,370.10 \pm 244.38^{\mathrm{a})}$ & 11.97 & & & \\
\hline & РОТ & $2,307.70 \pm 269.37$ & $2,710.20 \pm 334.95$ & $2,309.60 \pm 156.01^{a)}$ & 14.78 & Time & 2.24 & 0.126 \\
\hline & $\mathrm{CON}$ & $2,390.20 \pm 262.67$ & $2,242.60 \pm 713.95$ & $2,296.00 \pm 692.88^{a)}$ & -2.38 & Time $\times$ group & 3.35 & 0.050 \\
\hline
\end{tabular}

Values are presented as mean \pm standard deviation.

PRT, pretreatment group; POT, posttreatment group; CON, control group; ANOVA, analysis of variance.

${ }^{a}$ Statistically significant differences $(P<0.05)$ after Bonferroni post hoc.

tate showed a significant difference in the time $(F[2,26]=$ $136.69, P=0.001)$ and time $\times$ group interaction $(F[4,54]=2.56$, $P=0.049)$. The present results showed that the lactate concentration of recovery-30 min was lower in the low-pressure HBO-treated group after maximal exercise $(P=0.008)$.

\section{Heart rate}

The heart rate was presented in Table 3. The heart rate in the control group was $75.50 \pm 7.41$ beats/min before exercise, $182.60 \pm$ 7.24 beats $/ \mathrm{min}$ after exercise, and $97.80 \pm 7.48$ beats $/ \mathrm{min}$ after 30 min of recovery. Low-pressure HBO-treated group before maximal exercise was $75.00 \pm 9.20$ beats/min before exercise, $185.80 \pm 7.33$ beats/min after exercise, and $96.30 \pm 4.57$ beats $/ \mathrm{min}$ after $30 \mathrm{~min}$ of recovery. Low-pressure HBO-treated group after maximal exercise was $74.30 \pm 7.83$ beats/min before exercise, $184.70 \pm 8.00$ beats/min after exercise, and $86.50 \pm 10.93$ beats $/ \mathrm{min}$ after $30 \mathrm{~min}$ of recovery. Heart rate showed significant difference in the time
$(F[2,26]=3,045.80, P=0.001)$ and time $\times$ group interaction $(F[2$, $27]=3.92, P=0.032]$. The present results showed that the heart rate of recovery-30 min was lower in the low-pressure HBO -treated group after maximal exercise $(P=0.035)$.

\section{Antioxidant capacity}

The antioxidant capacity was presented in Table 4 . The antioxidant capacity in the control group was 2,390.20 $262.67 \mathrm{mmol}$ before exercise, 2,242.60 $\pm 713.95 \mathrm{mmol}$ after exercise, and 2,296.00 \pm $692.88 \mathrm{mmol}$ after $30 \mathrm{~min}$ of recovery. Low-pressure HBO-treated group before maximal exercise was 2,379.90 $\pm 168.89 \mathrm{mmol}$ before exercise, 2,692.50 $\pm 198.59 \mathrm{mmol}$ after exercise, and 2,370.10 \pm $244.38 \mathrm{mmol}$ after $30 \mathrm{~min}$ of recovery. Low-pressure HBO-treated group after maximal exercise was 2,307.70 $\pm 269.37 \mathrm{mmol}$ be-

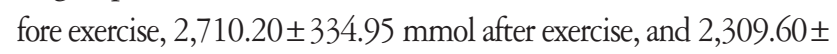
$156.01 \mathrm{mmol}$ after $30 \mathrm{~min}$ of recovery. The antioxidant capacity showed no significant in the time and time $\times$ group interaction. 


\section{DISCUSSION}

HBO therapy has been used as an adjunctive therapy for diseases, and the application of $\mathrm{HBO}$ therapy for the treatment of sports injuries has been proposed as a therapy for primary treatment or adjunctive therapy. In addition, HBO therapy has been shown to be effective in injuries associated with bones, muscles, and ligaments (Barata et al., 2011). In this study, we investigated the effects of low-pressure $\mathrm{HBO}$ treatment before and after maximal exercise on lactate concentration, heart rate and antioxidant capacity.

Lactate accumulation or muscle acidosis is a major determinant of fatigue (Allen et al., 2008). Lactate removal rate is a very important factor in exercise performance, and it means inhibition of anaerobic process (Karlsson et al., 1972). In the present study, the lowest lactate showed in the treated group with low-pressure HBO after maximal exercise compared with the control group and the treated group with low-pressure $\mathrm{HBO}$ before maximal exercise group. The physiological response of $\mathrm{HBO}$ and muscle metabolism are well known. High-pressure oxygen has been shown to increase arterial pressure and reduce heart rate (Lund et al., 1999), and hyperbaric conditions have been shown to reduce serum lactate accumulation during aerobic exercise (Neubauer et al., 1999; Stellingwerff et al., 2005). Ishii et al. (2005) reported that HBO treatment showed fast recovery of lactate in the athletes. In this study, the lactate removal effect of low-pressure HBO after maximal exercise was consistent with the results of Sueblinvong et al. (2004). Heart rate recovery is known to change in response to acute changes in training load (Perini et al., 2006). Lactate concentration is known to be closely related to heart rate ( $\mathrm{Ba}$ et al., 2009). An attenuated heart rate recovery after exercise has been shown to be predictive of fatigue (Watanabe et al., 2001). The present study showed that low-pressure HBO treatment showed significant change. However, the highest heart rate recovery showed in the treated group with low-pressure HBO after maximal exercise. These results suggest that low-pressure HBO treatment after maximal exercise alleviates the peripheral fatigue.

Oxygen is important for cellular energy systems, but excess oxygen can cause functional problems in the human body (Halliwell and Gutteridge, 1999). Early studies have shown that HBO treatment results in an increase in intracellular reactive oxygen species (Boveris and Chance, 1973; Yusa et al., 1987). However, many studies have shown an increase in antioxidant defense after exposure to high-pressure oxygen (Alcaraz-García et al., 2008; Dennog et al., 1996; Eken et al., 2005). The present results indicate that low-pressure HBO treatment before and after maximal exercise cannot mediate intracellular changes of antioxidant defense action.

Based on the present result, can be used as the new therapeutic agent for lactate control and fatigue recovery following exercise.

\section{CONFLICT OF INTEREST}

No potential conflict of interest relevant to this article was reported.

\section{ACKNOWLEDGMENTS}

This work was supported by College of Culture \& Sports, Korea University Research Fund of 2018.

\section{REFERENCES}

Alcaraz-García MJ, Albaladejo MD, Acevedo C, Olea A, Zamora S, Martínez P, Parra S. Effects of hyperoxia on biomarkers of oxidative stress in closed-circuit oxygen military divers. J Physiol Biochem 2008; 64:135-141.

Allen DG, Lamb GD, Westerblad H. Skeletal muscle fatigue: cellular mechanisms. Physiol Rev 2008;88:287-332.

Ba A, Delliaux S, Bregeon F, Levy S, Jammes Y. Post-exercise heart rate recovery in healthy, obeses, and COPD subjects: relationships with blood lactic acid and PaO2 levels. Clin Res Cardiol 2009;98:52-58.

Barata P, Cervaens M, Resende R, Camacho O, Marques F. Hyperbaric oxygen effects on sports injuries. Ther Adv Musculoskelet Dis 2011;3: 111-121.

Boveris A, Chance B. The mitochondrial generation of hydrogen peroxide. General properties and effect of hyperbaric oxygen. Biochem J 1973; 134:707-716.

Costill DL, Hargreaves M. Carbohydrate nutrition and fatigue. Sports Med 1992;13:86-92.

Dennog C, Hartmann A, Frey G, Speit G. Detection of DNA damage after hyperbaric oxygen (HBO) therapy. Mutagenesis 1996;11:605-609.

Edwards ML. Hyperbaric oxygen therapy. Part 1: history and principles. J Vet Emerg Crit Care (San Antonio) 2010;20:284-288.

Eken A, Aydin A, Sayal A, Ustündağ A, Duydu Y, Dündar K. The effects of hyperbaric oxygen treatment on oxidative stress and SCE frequencies in humans. Clin Biochem 2005;38:1133-1137.

Gomes EC, Silva AN, de Oliveira MR. Oxidants, antioxidants, and the beneficial roles of exercise-induced production of reactive species. Oxid Med Cell Longev 2012;2012:756132.

Halliwell B, Gutteridge JMC. Oxidative stress and antioxidant protection: some special cases. In: Halliwell B, Gutteridge JM, editors. Free radi- 
cals in biology and medicine. 3rd ed. Oxford: Clarendon Press; 1999. p. 530-533.

Ishii Y, Deie M, Adachi N, Yasunaga Y, Sharman P, Miyanaga Y, Ochi M. Hyperbaric oxygen as an adjuvant for athletes. Sports Med 2005;35: 739-746.

Karlsson J, Nordesjö LO, Jorfeldt L, Saltin B. Muscle lactate, ATP, and CP levels during exercise after physical training in man. J Appl Physiol 1972;33:199-203.

Lambeth JD. NOX enzymes and the biology of reactive oxygen. Nat Rev Immunol 2004;4:181-189.

Löndahl M. Hyperbaric oxygen therapy as treatment of diabetic foot ulcers. Diabetes Metab Res Rev 2012;28 Suppl 1:78-84.

Lund VE, Kentala E, Scheinin H, Klossner J, Helenius H, Sariola-Heinonen $\mathrm{K}$, Jalonen J. Heart rate variability in healthy volunteers during normobaric and hyperbaric hyperoxia. Acta Physiol Scand 1999;167: 29-35.

Neubauer B, Tetzlaff K, Buslaps C, Schwarzkopf J, Bettinghausen E, Rieckert $\mathrm{H}$. Blood lactate changes in men during graded workloads at normal atmospheric pressure (100 kPa) and under simulated caisson conditions (400 kPa). Int Arch Occup Environ Health 1999;72:178-181.

Perini R, Tironi A, Cautero M, Di Nino A, Tam E, Capelli C. Seasonal training and heart rate and blood pressure variabilities in young swimmers. Eur J Appl Physiol 2006;97:395-403.

Powers SK, Jackson MJ. Exercise-induced oxidative stress: cellular mechanisms and impact on muscle force production. Physiol Rev 2008;88: 1243-1276.
Reddy VP, Zhu X, Perry G, Smith MA. Oxidative stress in diabetes and Alzheimer's disease. J Alzheimers Dis 2009;16:763-774.

Robergs RA, Ghiasvand F, Parker D. Biochemistry of exercise-induced metabolic acidosis. Am J Physiol Regul Integr Comp Physiol 2004;287: R502-516.

Shimoda M, Enomoto M, Horie M, Miyakawa S, Yagishita K. Effects of hyperbaric oxygen on muscle fatigue after maximal intermittent plantar flexion exercise. J Strength Cond Res 2015;29:1648-1656.

Stellingwerff T, Glazier L, Watt MJ, LeBlanc PJ, Heigenhauser GJ, Spriet LL. Effects of hyperoxia on skeletal muscle carbohydrate metabolism during transient and steady-state exercise. J Appl Physiol (1985) 2005; 98:250-256.

Sueblinvong T, Egtasaeng N, Sanguangrangsirikul S. Hyperbaric oxygenation and blood lactate clearance: study in sixty male naval cadets. J Med Assoc Thai 2004;87 Suppl 2:S218-222.

Tibbles PM, Edelsberg JS. Hyperbaric-oxygen therapy. N Engl J Med 1996; 334:1642-1648.

Watanabe J, Thamilarasan M, Blackstone EH, Thomas JD, Lauer MS. Heart rate recovery immediately after treadmill exercise and left ventricular systolic dysfunction as predictors of mortality: the case of stress echocardiography. Circulation 2001;104:1911-1916.

Westerblad H, Allen DG, Lännergren J. Muscle fatigue: lactic acid or inorganic phosphate the major cause? News Physiol Sci 2002;17:17-21.

Yusa T, Beckman JS, Crapo JD, Freeman BA. Hyperoxia increases H2O2 production by brain in vivo. J Appl Physiol (1985) 1987;63:353-358. 